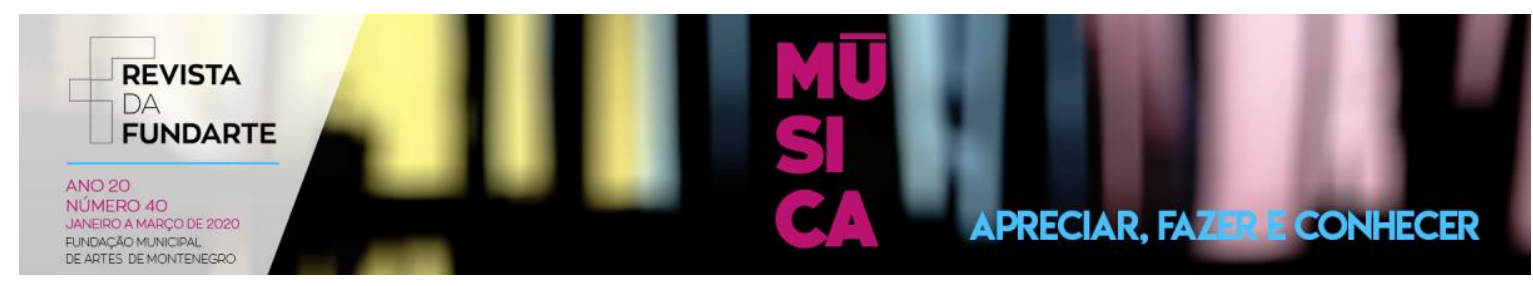

\title{
A CONSTRUÇÃO DA DISPOSIÇÃO NARRATIVA EM UMA PESQUISA (AUTO)BIOGRÁFICA SOBRE O DESPERTAR MUSICAL
}

Fernando Moreira Falcão Neto

Luiz Botelho Albuquerque

DOI: http://dx.doi.org/10.19179/2F2319-0868/2F760

FALCÃO NETO, Fernando Moreira; ALBUQUERQUE, Luiz Botelho. A construção da disposição narrativa em uma pesquisa (auto)biográfica sobre o despertar musical.Revista da FUNDARTE. Montenegro, p.166-187, ano 20, no 40, janeiro/março de 2020.Disponível em: http://.seer.fundarte.rs.gov.br/index.php/RevistadaFundarte/index> 31 de março de 2020 


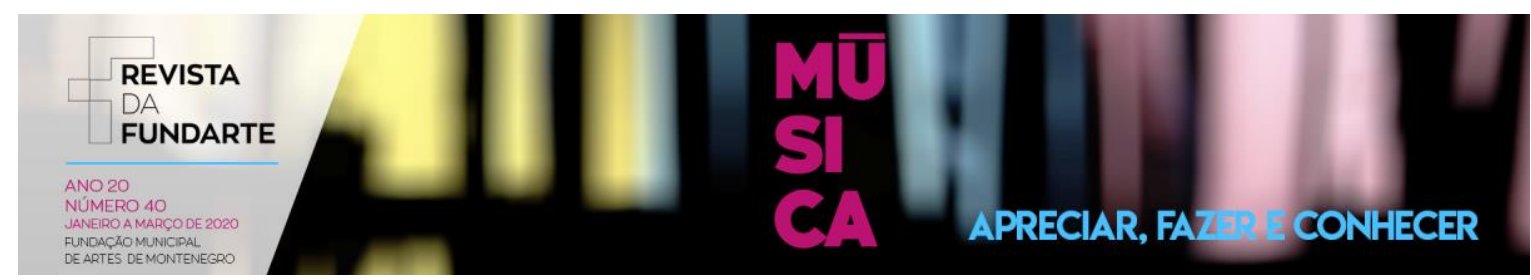

\title{
A CONSTRUÇÃO DA DISPOSIÇÃO NARRATIVA EM UMA PESQUISA (AUTO)BIOGRÁFICA SOBRE O DESPERTAR MUSICAL
}

Fernando Moreira Falcão Neto ${ }^{1}$ Luiz Botelho Albuquerque ${ }^{2}$

Resumo: Nesta publicação, compartilha-se o processo de investigação metodológica para o desenvolvimento de uma pesquisa sobre iniciações musicais em Fortaleza. Orientado pelo objetivo de acompanhar o processo do despertar musical de estudantes de escolas públicas, optou-se por desenvolver uma pesquisa (auto)biográfica, na qual estruturou-se um ateliê nomeado Círculo Reflexivo Biográfico (CRB). O dispositivo permite a construção gradual de uma abertura narrativa dos agentes colaboradores da pesquisa. Como resultado inicial, apresenta-se discussão sobre narrativas elaboradas com o uso da linguagem visual.

Palavras-chave: Despertar musical; Estudantes de escolas públicas; Pesquisa (auto)biográfica.

\section{THE CONSTRUCTION OF THE NARRATIVE DISPOSITION IN AN (AUTO)BIOGRAPHICAL RESEARCH ON MUSICAL AWAKENING}

\begin{abstract}
In this publication, the process of methodological investigation for the development of research on musical initiations in Fortaleza is shared. Guided by the objective of accompanying the musical awakening process of students from public schools, to develop an (auto)biographical research, in which an atelier named as the Biographical Reflective Circle (BRC). The device allows the gradual construction of a narrative opening of the collaborating agents of the research. As an initial result, a discussion is presented about the narratives elaborated using visual language.
\end{abstract}

Keywords: Musical awakening; Public school students; (Auto)biographical research.

\section{INTRODUÇÂO}

Em Fortaleza, a Universidade Federal do Ceará (UFC) possui três campi: Campus do Benfica, Campus do Porangabuçu e Campus do Pici Professor Prisco Bezerra. Este último é a maior área da Universidade, na capital. Em determinado ponto, parte do bairro ao redor, o Pici, adentra o campus. As casas populares, algumas com tijolos aparentes, contrastam com as janelas de vidros das unidades

\footnotetext{
1 Jornalista, Designer Educacional e mestrando do Programa de Pós-graduação em Educação da Universidade Federal do Ceará (UFC). Bolsista do Conselho Nacional de Desenvolvimento Científico e Tecnológico (CNPq).

${ }^{2}$ Graduado em Música Composição e Regência pela Universidade de Brasília (1971), Mestre em Educação pela Universidade Federal do Rio Grande do Sul (1980) e Doutor em Sociologia da Educação - University of lowa (1990). Atualmente é Professor Associado II lotado no Departamento de Teoria e Prática do Ensino da Faculdade de Educação da Universidade Federal do Ceará. Atua também junto ao Curso de Licenciatura em Música do Instituto de Cultura e Arte da UFC e junto ao Mestrado Profissionalizante em Artes PROFARTES/UFC. Tem experiência na área de Educação, com ênfase em Fundamentos da Educação, atuando principalmente nos seguintes temas: Sociologia da Educação; Sociologia da Arte e Música; Ensino de Musica, Educação e Formação de Professores.
}

FALCÃO NETO, Fernando Moreira; ALBUQUERQUE, Luiz Botelho. A construção da disposição narrativa em uma pesquisa (auto)biográfica sobre o despertar musical.Revista da FUNDARTE. Montenegro, p.166-187, ano 20, no 40, janeiro/março de 2020.Disponível em: http://.seer.fundarte.rs.gov.br/index.php/RevistadaFundarte/index> 31 de março de 2020 


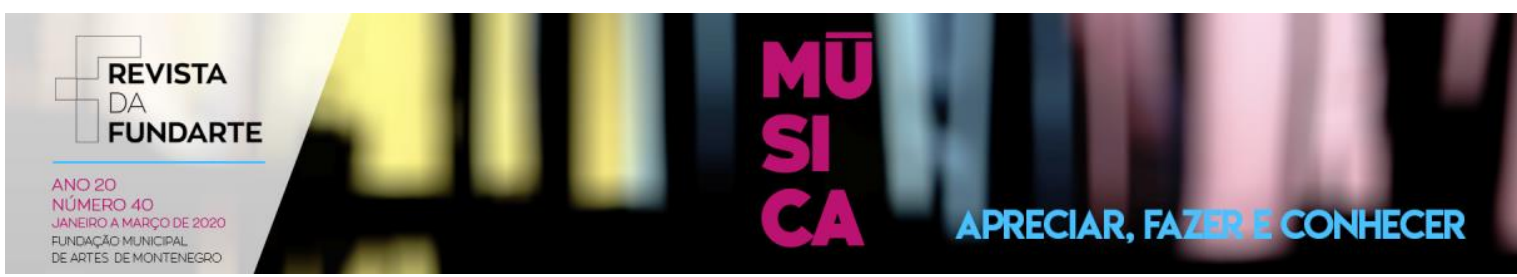

acadêmicas. Se caminharmos um pouco mais, chegaremos ao Dom Lustosa, outro bairro popular. Entre os dois bairros está a Rua Coronel Matos Dourado. Nesta rua limite, cercada pelas ruelas e becos que nos levam ao interior do Pici, encontramos a Escola Estadual de Educação Profissional (EEEP) Júlia Giffoni, uma escola profissionalizante de ensino médio.

No primeiro sábado de fevereiro de 2020, fomos à esta escola. Desde agosto do ano anterior, repetimos o mesmo ritual sem dificuldades: atravessar as grades dos dois extremos do hall de entrada e passar pelo pátio principal, para chegar ao terceiro pavilhão de salas. Neste corredor, próximo à quadra, entre os ambientes que abrigam as turmas técnicas de redes de computadores, finanças e estética, encontramos a sala de artes, nosso destino naquele sábado. A sala funciona como um estúdio para ensaios. Este é o abrigo do grupo Phylos, um coral cênico-musical especializado em música cearense.

Silva (2016), em sua dissertação, questionou sobre como a proposta educacional do grupo direcionava o gosto e a prática musical dos estudantes. Orientamos a nossa atenção para o que despertou o desejo da prática musical nesses estudantes: como chegaram até o Phylos? Ostrower (1987) considera a criatividade como aspecto essencial do constituir-se humano. A pulsão por criar está relacionada à necessidade de construir sentindo a si mesmo. A criação de formas externas ressoa a busca por dar forma a si. Desta maneira, se humanizar é inserirse em um mundo de sentidos compartilhados, reproduzindo e criando possibilidades semânticas ao agir. Assim, para a autora, o ser humano se constitui essencialmente como um ser formador de si e do mundo.

Contudo, Ostrower (idem) nos alerta que o sentir, o pensar, o desejar e o agir são social e historicamente localizados, mas não são estáticos. O mundo cultural ao qual cada um de nós tem acesso apresenta um campo de possibilidades semânticas à nossa criação. Ao agirmos, reconhecemos as formas existentes e as colocamos em movimento. Assim, a semântica cultural se configura como um campo-macro em expansão permanente, no qual a escola apresenta-se como instituição importante para o acesso e validação de modos de agir culturalmente. Esta instituição nos fornece, com o currículo, modos de sentir, pensar e fazer que direcionam a nossa FALCÃO NETO, Fernando Moreira; ALBUQUERQUE, Luiz Botelho. A construção da disposição narrativa em uma pesquisa (auto)biográfica sobre o despertar musical.Revista da FUNDARTE. Montenegro, p.166-187, ano 20, no 40, janeiro/março de 2020.Disponível em: http://.seer.fundarte.rs.gov.br/index.php/RevistadaFundarte/index> 31 de março de 2020 


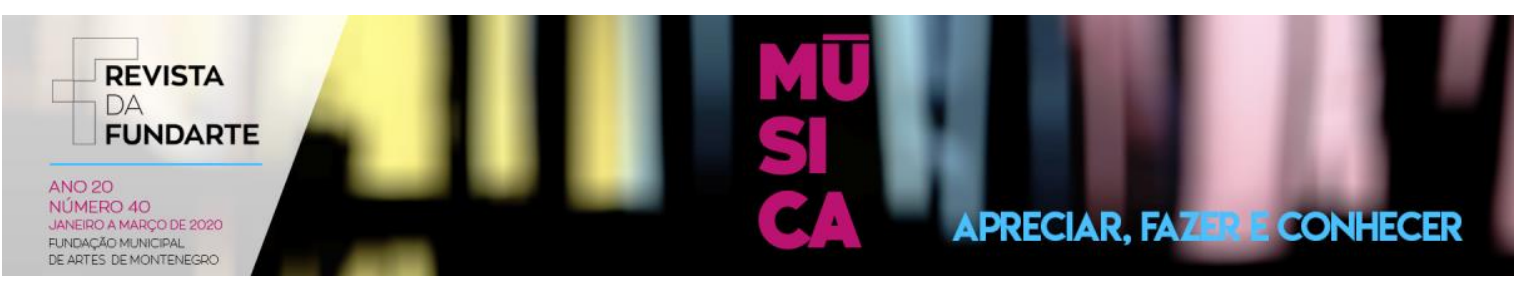

inserção cultural. Neste espaço, não apenas acessamos linguagens e aprendemos a dominar técnicas, como a escrita, mas também damos formas ao nosso modo de perceber, interpretar e direcionar o nosso agir social e cultural. O ensino da técnica, o que compreendemos como supervalorizado pela cultural ocidental colonial, é a função mais simples exercida pela escola. A complexa tarefa de fornecer possibilidades semânticas ao direcionamento da inserção cultural e do agir social é o que sustenta a existência desta instituição. O currículo reverbera o que socialmente é compreendido como valoroso e necessário.

Em sua pesquisa com o grupo Phylos, Silva (2016) compreende o gosto como uma construção social e, referenciado por Bourdieu, o afirma como um mecanismo de distinção social. Para o autor, as necessidades culturais são produzidas pela educação. Percebemos que esta função não cabe apenas à escola, mas esta institucionaliza e formaliza propostas curriculares que priorizam, legitimam conhecimentos e afazeres específicos. Com esta perspectiva, a pesquisa de Silva reconhece a proposição do coral da EEEP Júlia Giffoni como relevante contribuição para o acesso à produção de artistas cearenses sem espaço na mídia de massa. Além do conhecer e do consumir o trabalho de artístas locais, a proposta pedagógica amplifica as possibilidades semânticas não apenas para a ação, mas também para a construção da poética particular desses artistas em formação. Compreendemos como poética o modo de sentir, interpretar e criar significado ao mundo cultural no qual se encontra imerso.

Procuramos o grupo Phylos em junho de 2019. Antes disso, compreendemos que, para nos aproximarmos dos movimentos subjetivos que provocaram a procura pela proposta educacional e musical do grupo, seria necessário estabelecer relação intersubjetiva entre pesquisador e colaboradores. Para isso, com o grupo de pesquisa Dialogicidade, Formação Humana e Narrativas (DIAFHNA), encontramos o Círculo Reflexivo Biográfico (CRB), dispositivo de pesquisa elaborado pela professora Ercília de Olinda (2009). Este procedimento estrutura a ambientação e o processo de produção das narrativas autobiográficas.

O primeiro contato com o Phylos foi por e-mail, enviado a um dos coordenadores, o professor Fabrício Maciel. Semanas depois, Fabrício, que também FALCÃO NETO, Fernando Moreira; ALBUQUERQUE, Luiz Botelho. A construção da disposição narrativa em uma pesquisa (auto)biográfica sobre o despertar musical.Revista da FUNDARTE. Montenegro, p.166-187, ano 20, no 40, janeiro/março de 2020.Disponível em: http://.seer.fundarte.rs.gov.br/index.php/RevistadaFundarte/index> 31 de março de 2020 


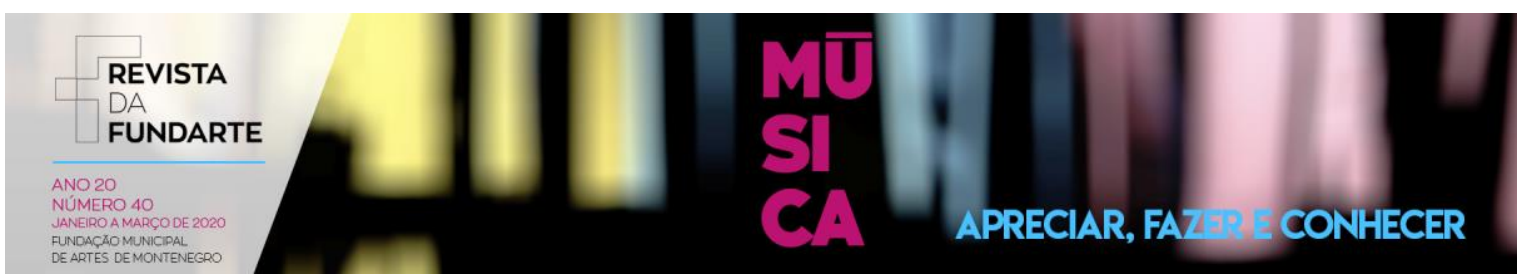

é regente do coral, pediu para o pesquisador gravar áudios no aplicativo WhatsApp, explicando a proposta. Os áudios foram encaminhados aos coralistas, neste aplicativo. Dias depois, o pesquisador foi inserido em um outro grupo intitulado Mestrado, no mesmo aplicativo. Neste ambiente, foi proposto o $\mathrm{CRB}$, com quatro encontros presenciais e três a distância, em um Ambiente Virtual de Aprendizagem (AVA). Nomeamos o nosso espaço no AVA como Círculo Reflexivo Biográfico Musical (CRBM), realizado entre setembro de 2019 e fevereiro de 2020. O coral precisava escolher quatro participantes, os critérios seriam: ser coralista do Phylos e ser estudante ou egresso de escola pública. Uma quinta participante não seria coralista, mas uma professora de música ex-estagiária do Phylos. Todos os participantes cursaram ou cursam o ensino médio em escolas públicas de Fortaleza.

Neste texto, começamos a discutir sobre os movimentos narrativos produzidos durante o CRBM. Nos próximos tópicos, compartilhamos o processo de estruturação metodológica, apresentamos o contexto da relação dos colaboradores com o campo e concluímos com discussão inicial sobre o uso da linguagem visual como ato narrativo.

\section{PROPOSTA METODOLÓGICA: O CÍRCULO REFLEXIVO BIOGRÁFICO}

Ao propor o projeto, agora intitulado Pesquisa (auto)biográfica sobre iniciações musicais em Fortaleza: estudo de contexto para design educacional, questionávamos como se constituía a escolha por um determinado afazer. Direcionávamos o questionamento à procura por agir artisticamente. O diálogo com pesquisas, como as de Rogério (2006), sobre o coletivo Pessoal do Ceará, e Silvino (2007), investigação autobiográfica sobre a sua formação como musicista e educadora, nos ajudou a perceber que cabia aos próprios agentes reconhecerem, ordenarem e narrarem as experiências que identificam como motoras da sua busca musical.

A carta da Associação Internacional das Histórias de Vida em Formação, ASIHVIF (2016), compreende que a perspectiva que orienta as práticas de narrativas de si é a busca pela emancipação humana, nos âmbitos pessoal e social. Essa perspectiva provoca o que o texto afirma como recusa do afastamento entre FALCÃO NETO, Fernando Moreira; ALBUQUERQUE, Luiz Botelho. A construção da disposição narrativa em uma pesquisa (auto)biográfica sobre o despertar musical.Revista da FUNDARTE. Montenegro, p.166-187, ano 20, no 40, janeiro/março de 2020.Disponível em: http://.seer.fundarte.rs.gov.br/index.php/RevistadaFundarte/index> 31 de março de 2020 


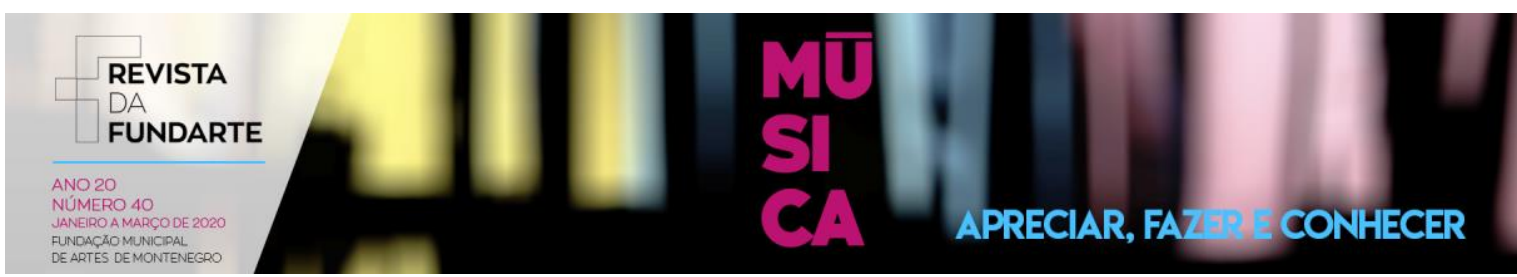

teoria e prática. Assim, se estabelece uma busca por modos de produzir narrativas de si, individuais ou em grupo, que não se conformem:

[...] à distribuição hierarquizada dos lugares do pesquisador, do prático e do sujeito narrador (indivíduo ou grupo). A Associação entende sua substituição por uma relação dialética, na qual as teorias interrogam as práticas e vice-versa. Ela espera, por conseguinte, um efeito de renovação, ao mesmo tempo, no campo das práticas de pesquisa, de formação e de intervenção, e no campo da teorização, mais especificamente, na educação permanente e na formação de adultos. (ASIHVIF, 2016, p. 178).

A proposta é que o narrador esteja no centro do processo, como o responsável por definir o que busca e a direcionar o seu "projeto de compreensão de si para si, pela mediação do outro" (idem, p. 177). A carta não possui a função de manual normalizador ou de diretriz ética, mas sim de compartilhamento de um posicionamento ético-político-epistêmico. Pineau (2006), ao elaborar um panorama de 25 anos (1980 a 2005) do movimento das histórias de vida, o considera como resultante de uma crise paradigmática histórica que levou à busca por novas práxis socioformadoras. Esse processo provocou a elaboração de novas situações de interlocução para a produção de conhecimento e a não aceitação de um modo ordinário de se fazer pesquisa.

O autor considera que esse posicionamento avança na América do Sul devido a busca por reconhecer o direito de agentes sociais, até então, percebidos como objetos e ignorados como autores, de produzir conhecimento sobre si. Desta forma, essa perspectiva se constitui como práxis socioeducativa de pesquisa-açãoformação, elaborada a partir de questionamentos de pesquisa produzidos em meio a "difícil passagem do paradigma da ciência aplicada ao do ator reflexivo" (PINEAU, 2006, p. 336). Como movimento, possui como aposta biopolítica a:

[...] reapropriação, pelos sujeitos sociais, da legitimidade de seu poder de refletir sobre a construção de sua vida. Essa vida não é completamente préconstruída. E ela é muito complexa para ser construída unicamente pelos outros. Novas artes formadoras da existência são inventadas. (PINEAU, 2006, p. 336).

Não se trata de dar voz, mas sim de oferecer escuta e reconhecimento à legitimidade do outro saber e produzir sobre si. $O$ ato narrativo reorganiza experiências e cria novos significados. Neste sentido, Ferrarotti (2010) considera a FALCÃO NETO, Fernando Moreira; ALBUQUERQUE, Luiz Botelho. A construção da disposição narrativa em uma pesquisa (auto)biográfica sobre o despertar musical.Revista da FUNDARTE. Montenegro, p.166-187, ano 20, no 40, janeiro/março de 2020.Disponível em: http://.seer.fundarte.rs.gov.br/index.php/RevistadaFundarte/index> 31 de março de 2020 


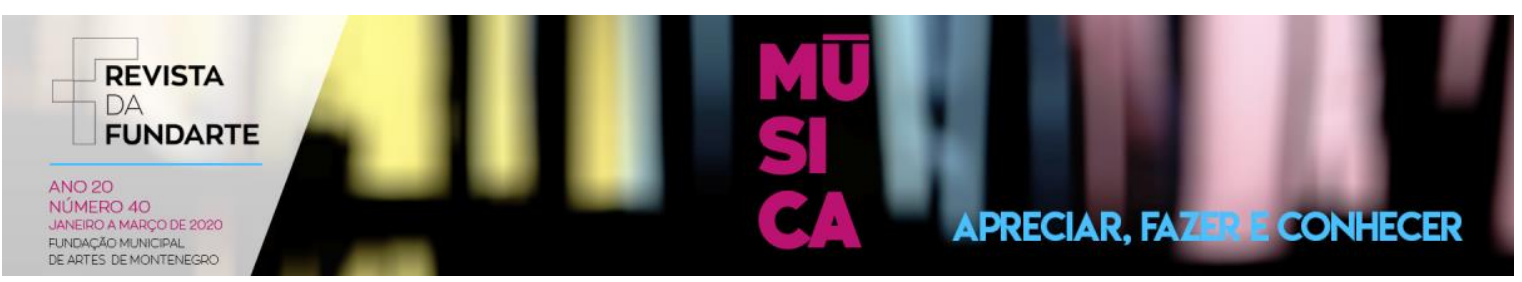

biografia como constituída de subjetividade e, por esta razão, antinomotética. As problemáticas contemporâneas fizeram emergir 0 questionamento do distanciamento entre sujeito e objeto, a provocar uma necessidade de renovação metodológica. A procura é por compreender a vida cotidiana com as suas dificuldades e contradições. Surge o que o autor denomina como ciência das mediações, direcionada ao microssocial, a considerar toda prática humana como atividade sintética das relações sociais. As narrativas biográficas constituem uma "síntese vertical de uma história social" (p. 44) (figura 1):

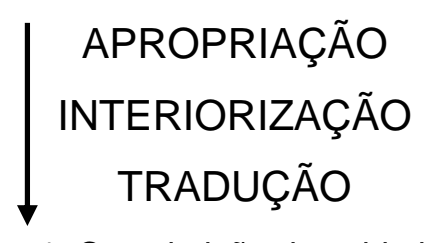

Figura 1: Constituição da subjetividade.

Fonte: produção própria.

Direciona-se o olhar para uma prática individual em busca de compreender o social, o que faz necessária uma hermenêutica da interação. Para Ferrarotti, "as formas e os conteúdos de uma narrativa biográfica variam com o interlocutor" (idem,p.46). Por essa razão, há a necessidade de estabelecer uma interação recíproca. Quanto maior esta interação, maior a possibilidade de acompanhamento do processo particular e dialético de desestruturar-reestruturar os funcionamentos sociais. É neste diálogo com o externo que o sujeito se constitui: "o observador encontra-se ridiculamente implicado no campo do seu objeto. Este último, longe de ser passivo, modifica continuamente o seu comportamento em função do comportamento do observador" (FERRAROTTI, 2010, p. 49).

Desta forma, para o autor, a produção do conhecimento é intersubjetiva, produzida pela interação entre um indivíduo e um sistema social. Bourdieu (2012) interpreta que a nossa ação no mundo se estabelece a partir da incorporação de habitus, o que compreendemos como uma rede de possibilidades à ação. Para o autor, a estrutura social se configura como um grande campo, constituído por (sub)campos autônomos. Esses, com as relações que se configuram nos seus interiores, estabelecem padrões de reconhecimento e legitimidade à ação dos

FALCÃO NETO, Fernando Moreira; ALBUQUERQUE, Luiz Botelho. A construção da disposição narrativa em uma pesquisa (auto)biográfica sobre o despertar musical.Revista da FUNDARTE. Montenegro, p.166-187, ano 20, no 40, janeiro/março de 2020.Disponível em: http://.seer.fundarte.rs.gov.br/index.php/RevistadaFundarte/index> 31 de março de 2020 


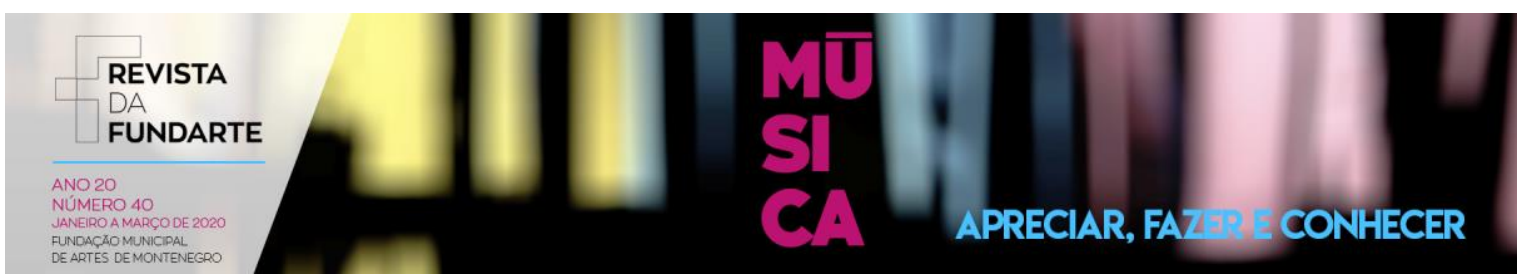

agentes autorizados a agirem a partir de diferentes lugares sociais. A inserção cultural e o agir social se estabelecem na circulação por diferentes (sub)campos. No interior desses campos autônomos, vão se configurando a autorização e o limite da agência individual. Interpretamos o conceito de habitus como uma semântica estabelecida à ação cultural. Inserir-se em diversos campos ampliaria o capital cultural e, consequente, a capacidade de interferir na estruturação dos habitus dos diferentes campos aos quais o agente social pertence.

A perspectiva reconhece na estrutura social os direcionamentos dados à ação do agente. Ostrower (1987), por sua vez, compreende que o direcionamento da ação ocorre no processo de interiorização e tradução do mundo social. Bondía (2015) afirma que só há aprendizado verdadeiro quando se encontra o próprio dizer, possível apenas com a experiência, que ocorre com o ato de interiorizar e traduzir os acontecimentos. Atividades e informações repetidas não provocam a experiência, portanto, não resultam em aprendizagem. A reprodução de dados e fatos conduzem ao automatismo reescrita da fala do outro. Isto impede o humano de se realizar como um ser formador.

$\mathrm{O}$ ato de narrar sobre si possibilita que o próprio agente reconheça a semântica cultural disponível nos diferentes campos nos quais possui inserção. A produção da narrativa nos possibilita acompanharmos 0 ato de reconhecimento, ordenação e encadeamento de experiências. Isto permite maior proximidade com os processos de apropriação, interiorização e tradução particulares. Contudo, quanto maior for a troca intersubjetiva, maior será a disponibilidade narrativa do agente. $\mathrm{A}$ carta da ASIHVIF (2016) alerta para a necessidade de se estabelecer um clima de confiança mútua para a produção da narrativa. Aqui, retornamos à citação de Ferrarotti da página anterior, para afirmarmos que não compreendemos os agentes do contexto pesquisado como objeto, mas sim como agentes-colaboradores da investigação proposta. Feita a ressalva, compartilhamos com 0 autor 0 reconhecimento à implicação inerente a pesquisas relacionais.

Com esta perspectiva, reconhecemos que os procedimentos desenvolvidos em campo precisam corresponder aos objetivos da pesquisa, mas também, às necessidades e possibilidades do contexto de investigação. Nosso propósito inicial FALCÃO NETO, Fernando Moreira; ALBUQUERQUE, Luiz Botelho. A construção da disposição narrativa em uma pesquisa (auto)biográfica sobre o despertar musical.Revista da FUNDARTE. Montenegro, p.166-187, ano 20, no 40, janeiro/março de 2020.Disponível em: http://.seer.fundarte.rs.gov.br/index.php/RevistadaFundarte/index> 31 de março de 2020 


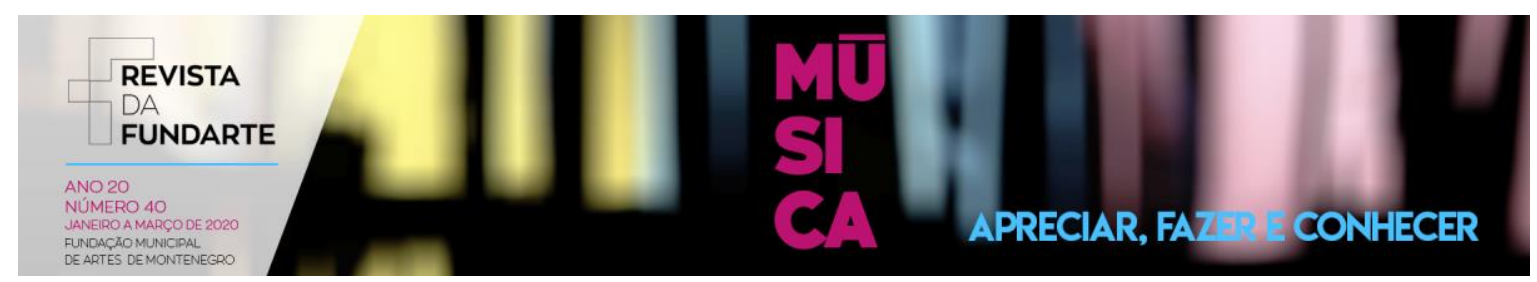

foi o de oferecer um espaço de escuta aos agentes-colaboradores. Entre diferentes possibilidades de modos de agir em campo, encontramos o CRB, proposto como um ateliê de narrativa que apresentou a possibilidade de desenvolvermos, gradativamente, a aproximação e a disponibilidade narrativa necessárias. O procedimento orienta o uso de diferentes linguagens para se trabalhar o ser humano em sua integralidade. Santaella (2005), ao falar da origem da linguagem e do pensamento, nos apresenta três matrizes de linguagem:

a) Sonora - tem como eixo fundamental a sintaxe: combinação de elementos (sons, alturas e durações);

b) Visual - tem como propriedade a forma;

c) Verbal - capacidade de verbalização.

Ao considerarmos as matrizes de linguagem e o fato de não serem puras, mas híbridas, decidimos inserir o hipertexto, que, com o uso de ferramentas digitais, permite a incorporação das matrizes sonora e visual à matriz verbal. Para isso, incorporamos à proposta do CRB a utilização de um AVA, plataforma com característica de hipermídia, ambiente que permite acesso a diferentes mídias em um mesmo espaço virtual. Isto possibilita a criação com todas as matrizes de linguagem e, desta forma, ampliamos as possibilidades das construções narrativas.

O CRB surgiu como Círculo Reflexivo sobre Experiência Religiosa (CRER), dispositivo elaborado durante pesquisa de pós-doutorado de Olinda (2009) em Ciência da Religião. Ao pesquisar sobre a dimensão formadora e espiritual da participação de jovens no movimento espírita, ela elaborou procedimento de pesquisa que possibilitou estruturar a inserção em campo a partir de uma perspectiva holística. Para isso, a pesquisadora se predispôs a estar exposta ao campo, aberta às experiências que este poderia provocar (Bondía, 2015). Apenas deste modo, foi possível estabelecer uma relação intersubjetiva entre todos os participantes, pesquisadora e colaboradores (Ferrarotti, 2010). A autora indica que a proposição surgiu do diálogo entre dois campos teóricos-metodológicos: a pesquisa (auto)biográfica e a pedagogia libertadora. O primeiro campo teórico contribuiu com pressupostos e práticas como os ateliês biográficos de Delory-Momberger e os trabalhos com as experiências de vida em formação de Christine Josso. O segundo FALCÃO NETO, Fernando Moreira; ALBUQUERQUE, Luiz Botelho. A construção da disposição narrativa em uma pesquisa (auto)biográfica sobre o despertar musical.Revista da FUNDARTE. Montenegro, p.166-187, ano 20, no 40, janeiro/março de 2020.Disponível em: http://.seer.fundarte.rs.gov.br/index.php/RevistadaFundarte/index> 31 de março de 2020 


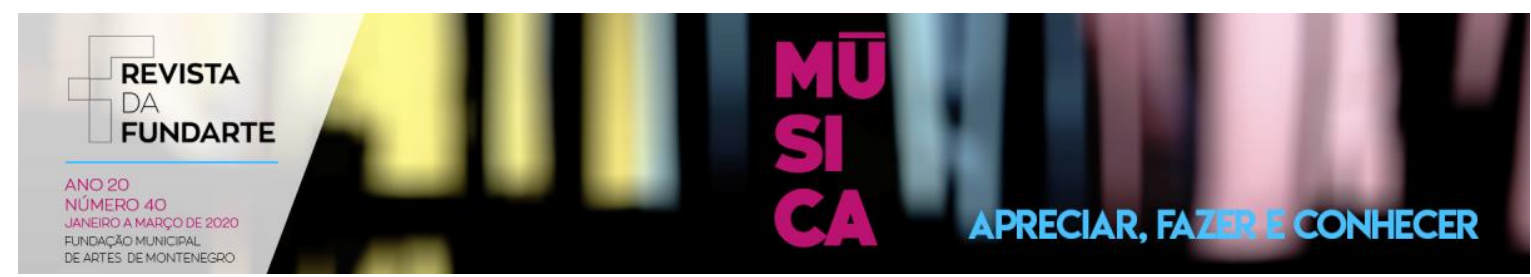

campo inspirou com os princípios e a proposição dos círculos de cultura de Paulo Freire.

Os pressupostos e os procedimentos adotados para estudar o contexto e preparar a ambientação para o desenvolvimento da pesquisa asseguraram o rigor necessário para a produção científica com subjetividades. Isto proporcionou o que a pesquisadora refere-se como mergulho profundo nas percepções dos colaboradores. Cada encontro do CRB possui 4 momentos: acolhida, demonstração que a história e a ação do colaborador são importantes; presentificação, direcionamento da atenção ao seu desenvolvimento cognitivo, corporal, espiritual e afetivo; biografização, conjunto de atividades que utilizam diferentes linguagens para elaboração da biografia educativa; integração experiencial, realizada ao fim de cada encontro para integrar as experiências e avaliar o encontro.

O procedimento estrutura-se para proporcionar a produção do que Ricoeur (1994) denomina como intriga narrativa, que é o próprio ato de narrar. Para o autor é a interação comunicativa que atribui significados e configura a realidade que compartilhamos. Com este ato, colocamos em movimento as possibilidades semânticas à nossa criação. Tomamos parte do mundo pela narrativa. $O$ autor organiza esse processo em três etapas (figura 2): prefiguração, referente ao ato de ter experienciado, o que é histórica e socialmente limitado; configuração, a organização da própria narrativa, o encadear experiências para formar uma história; por fim, a reconfiguração, que é o retorno ao tempo da ação, o ato de narrar e ouvir.

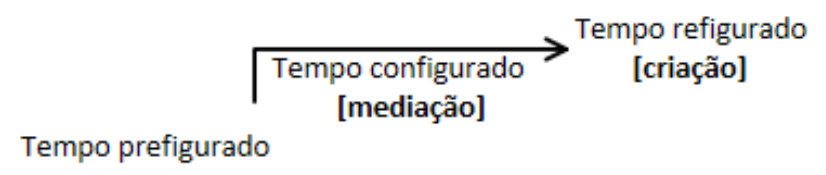

Figura 2: Tríplice mimese elaborada por Ricouer. Fonte: produção própria.

Os processos do CRB foram elaborados para proporcionar a vivência sistêmica de cada etapa indicada no modelo proposto por Ricoeur. Para o CRBM, com a inclusão do espaço virtual, as atividades dos encontros presenciais iniciavam no AVA, desenvolvido em parceria com o Grupo de Estudo sobre Educação Online do Laboratório Multimeios (Geom). No Phylos, os colaboradores se encontraram em FALCÃO NETO, Fernando Moreira; ALBUQUERQUE, Luiz Botelho. A construção da disposição narrativa em uma pesquisa (auto)biográfica sobre o despertar musical.Revista da FUNDARTE. Montenegro, p.166-187, ano 20, no 40, janeiro/março de 2020.Disponível em: http://.seer.fundarte.rs.gov.br/index.php/RevistadaFundarte/index> 31 de março de 2020 


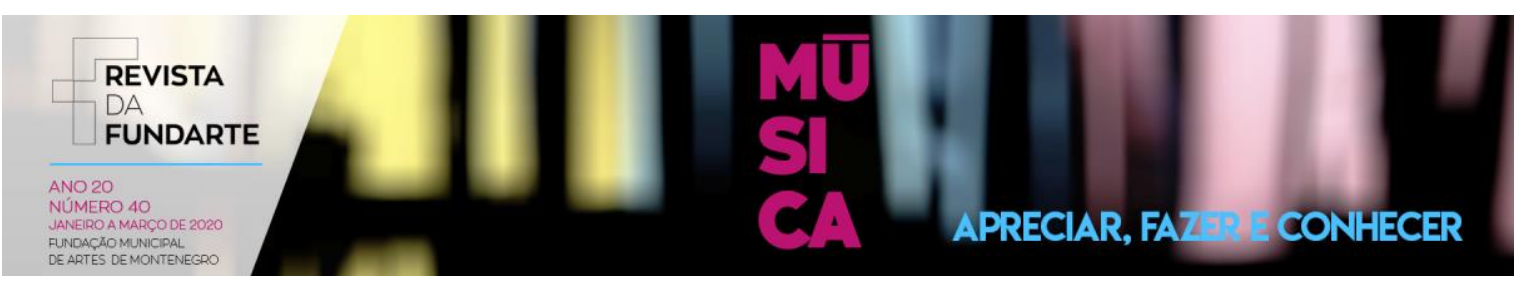

uma proposição de educação que trabalha a pesquisa musical e cênica com um repertório identificado como música cearense. Por reconhecermos os direcionamentos estéticos dados ao desenvolvimento artístico dos estudantes, elegemos como temática do CRBM a estética da xilogravura com figuras identificadas como cearenses. Encontramos a construção desta estética identitária em autores como Leonardo Mota (2002), Gustavo Barroso (1912) e Juvenal Galeno (1969), com narrativas que recorrem, por exemplo, ao sol e ao vaqueiro como ícones característicos da terra local.

Como atividade de acolhida, criamos um fórum intitulado Caixa de Música, no qual, durante o intervalo entre um encontro e outro, os participantes compartilharam músicas. O que permitiu perceber com quais músicas todos os participantes, inclusive o pesquisador, se narram publicamente. A cada encontro presencial, existiam dois colaboradores responsáveis por apresentar uma síntese do que foi compartilhado na Caixa de Música. Boa parte das trocas musicais aconteceram não no AVA, mas sim no WhatsApp, espaço no qual os colaboradores já estavam inseridos antes do CRBM. Assim, as acolhidas, em todos os encontros presenciais, foram realizadas com música.

Para a atividade de presentificação e síntese integradora, nos inspiramos em garrafinhas ornamentais, com desenhos de paisagens cearenses, produzidas com areias coloridas extraídas de praias. A cada início de encontro presencial, os colaboradores escolhiam uma cor para indicar como se sentiam naquele instante. Ao término, repetíamos a ação, com uma fala sobre o processo vivenciado no dia. Nomeamos a atividade como As Cores do Ceará, no quarto tópico, compartilhamos o início da discussão sobre essa nuance da produção narrativa.

\section{O CONTEXTO: A BUSCA POR MÚSICA EM FORTALEZA}

Entre os cinco colaboradores, dois são menores de idade, por esta razão não os identificamos pelos seus nomes civis. Utilizamos a questão ética como oportunidade para elaborar uma atividade que possibilitou mais um espaço para refletir sobre si e a sua prática artística. Antes do primeiro encontro presencial, que ocorreu no dia 21 de setembro de 2019, criamos no AVA um fórum intitulado 0 FALCÃO NETO, Fernando Moreira; ALBUQUERQUE, Luiz Botelho. A construção da disposição narrativa em uma pesquisa (auto)biográfica sobre o despertar musical.Revista da FUNDARTE. Montenegro, p.166-187, ano 20, no 40, janeiro/março de 2020.Disponível em: http://.seer.fundarte.rs.gov.br/index.php/RevistadaFundarte/index> 31 de março de 2020 


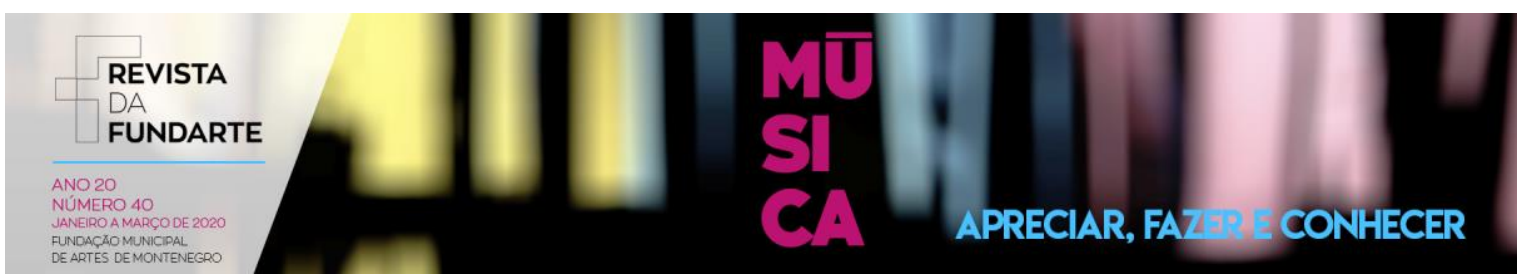

nome do Eu Lírico. A proposta era escolher não apenas um pseudônimo, mas criar o nome que melhor se refira ao artista que buscam ser. O pesquisador foi o primeiro a apresentar um novo nome: Pirambu Jurema. Os agentes-colaboradores da pesquisa apresentaram os novos nomes a partir do segundo encontro presencial, no dia 5 de outubro: Carlos Joaninha, 20 anos, Girassol, 17 anos, MeuCantoSophia, 25 anos, e Sky, 20 anos. No dia 10 de dezembro, a última participante informou o nome escolhido: Birdie, 16 anos.

Escolher um nome para o artista que se é, possibilitou, a cada um, olhar para os motores de suas ações. Contudo, neste trabalho, não nos deteremos ao processo de elaboração dos novos nomes. Ao longo do CRBM, cada ato narrativo, seja com palavras ditas e cantadas ou objetos e cores, carrega consigo a busca por significar a si e a sua própria ação. A performance narrativa traz em si a procura por encontrar a sua própria palavra, o seu modo possível de sentir e expressar o mundo (Bondía, 2015).

A necessidade de criar uma forma para ordenar quem desejam ser os levou ao coral Phylos. Carlos Joaninha, Sky e Girassol são ex-alunos da EEEP Júlia Giffoni. Os dois primeiros concluíram o ensino médio na escola, ela cursou o técnico em estética e ele o de finanças. Ser egresso não significa o fim da relação com o Phylos. Carlos Joaninha mora próximo à escola, no Pici; trabalha de segunda à sexta-feira, às vezes, também aos sábados; faz cursinho preparatório para o Enem, deseja cursar direito e seguir a carreira diplomática; possui uma banda e faz parte do Phylos. Sky mora mais distante da escola, no Bonsucesso; cursa licenciatura em letras, na UFC; leciona no ensino fundamental; canta no Phylos e na companhia de teatro musical Sings, outro projeto abrigado na escola e também coordenado pelo professor Fabrício.

Girassol mora perto da escola, no Dom Lustosa. Após cursar o $1^{0}$ ano do ensino médio na EEEP Júlia Giffoni, pediu transferência para outra escola pública da região, mas toda semana retorna ao coral. No dia 03 de fevereiro de 2020, ela completou 17 anos, era início do ano letivo, nas escolas da rede estadual. Pela manhã, foi à aula e, à tarde, apresentou-se, com o Phylos, aos ingressantes do $1^{\circ}$ ano, na EEEP Júlia Giffoni. Sky e Birdie também participaram da apresentação. Um FALCÃO NETO, Fernando Moreira; ALBUQUERQUE, Luiz Botelho. A construção da disposição narrativa em uma pesquisa (auto)biográfica sobre o despertar musical.Revista da FUNDARTE. Montenegro, p.166-187, ano 20, no 40, janeiro/março de 2020.Disponível em: http://.seer.fundarte.rs.gov.br/index.php/RevistadaFundarte/index> 31 de março de 2020 


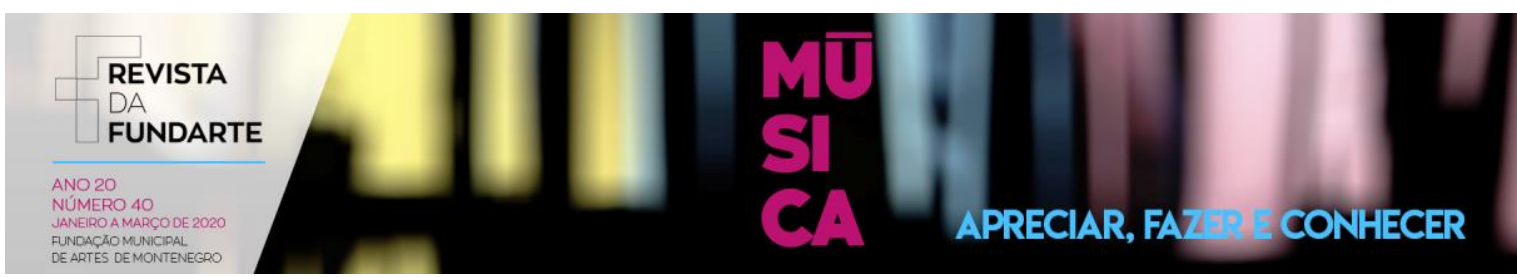

mesmo ritual se repetiu três vezes: antes de cada apresentação, todo o elenco corria para a sala de apoio, fechava a porta verde e aguardava os alunos entrarem na sala de artes. Apagavam as luzes, a porta se abria e a chama de uma vela acompanhava o início do canto: "aqui chegamos, chegamos aqui"3. Quando a sala se iluminava, era possível notar os olhares atentos e encantados da plateia. Os 25 minutos de espetáculo antecediam um bate-papo que iniciava com a surpresa dos estudantes por reconhecerem entre os artistas alguns dos colegas que conheceram naquele dia.

Birdie mora no Canindezinho, bairro distante do Pici, e não estuda naquela escola. As suas aulas iniciariam no dia seguinte mas, às 7 horas daquela segundafeira, estava na EEEP Júlia Giffoni, infiltrada como aluna do curso de estética e não tardou a fazer novas amizades. "Estão vendo? Isso é para mostrar que vocês também podem estar aqui na frente", provocou Fabrício, a incentivar que os novos estudantes participassem das audições, no sábado seguinte. As conversas compartilhadas naquela manhã foram suficientes para uma das recentes amigas, ao descobrir que Birdie não era da turma, não controlar o choro. "Não chora, não, mulher, senão eu também choro", disse Birdie, antes do abraço. Birdie não estuda em escola profissionalizante, mas também sonha em atuar no campo da estética corporal. Na tarde daquele sábado de fevereiro, ao iniciarmos o último encontro, compartilhou o seu entusiasmo por começar, na semana seguinte, um curso de design de sobrancelhas.

MeuCantoSophia mora em Maracanaú, município da região metropolitana de Fortaleza. Em uma conversa, no fim de 2017, comentou pela primeira vez com o pesquisador sobre um grupo coral que pesquisava e encenava espetáculos com música cearense. Um ano depois, ao ser procurada pelo pesquisador que queria conhecer mais sobre aquele grupo, contou que estava como professora estagiária do coral. MeuCantoSophia, que naquele momento estava a um semestre de concluir a licenciatura em música, procurara o grupo para conhecer um pouco mais sobre a música local. Esse desejo por aprender mais e por compartilhar o que a sua

\footnotetext{
${ }^{3}$ Música "Nós Ao Vivo" do artista Daniel Medina.

FALCÃO NETO, Fernando Moreira; ALBUQUERQUE, Luiz Botelho. A construção da disposição narrativa em uma pesquisa (auto)biográfica sobre o despertar musical.Revista da FUNDARTE. Montenegro, p.166-187, ano 20, no 40, janeiro/março de 2020.Disponível em: http://.seer.fundarte.rs.gov.br/index.php/RevistadaFundarte/index> 31 de março de 2020
} 


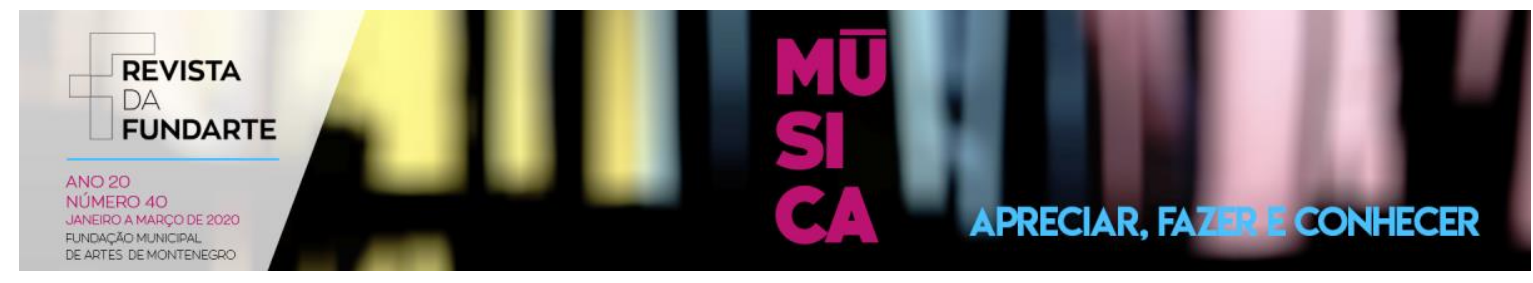

formação the proporcionara a levava, aos sábados pela manhã, àquela escola, no Pici. Em julho de 2019, quando organizamos as datas e horários para iniciarmos o CRBM, já graduada, MeuCantoSophia não trabalhava mais com o grupo. Porém, mesmo lecionando todos os sábados pela manhã, escolheu regressar àquela escola, alguns sábados à tarde, para participar do CRBM.

Não ter vínculo institucional com a escola ou a distância não impedem que estes colaboradores busquem a proposta de educação musical oferecida pelo Phylos. Abaixo (figura 3), mostramos a distância entre os bairros onde vivem os participantes e a EEEP Júlia Giffoni. Incluímos o pesquisador, morador de Caucaia, na região metropolitana.

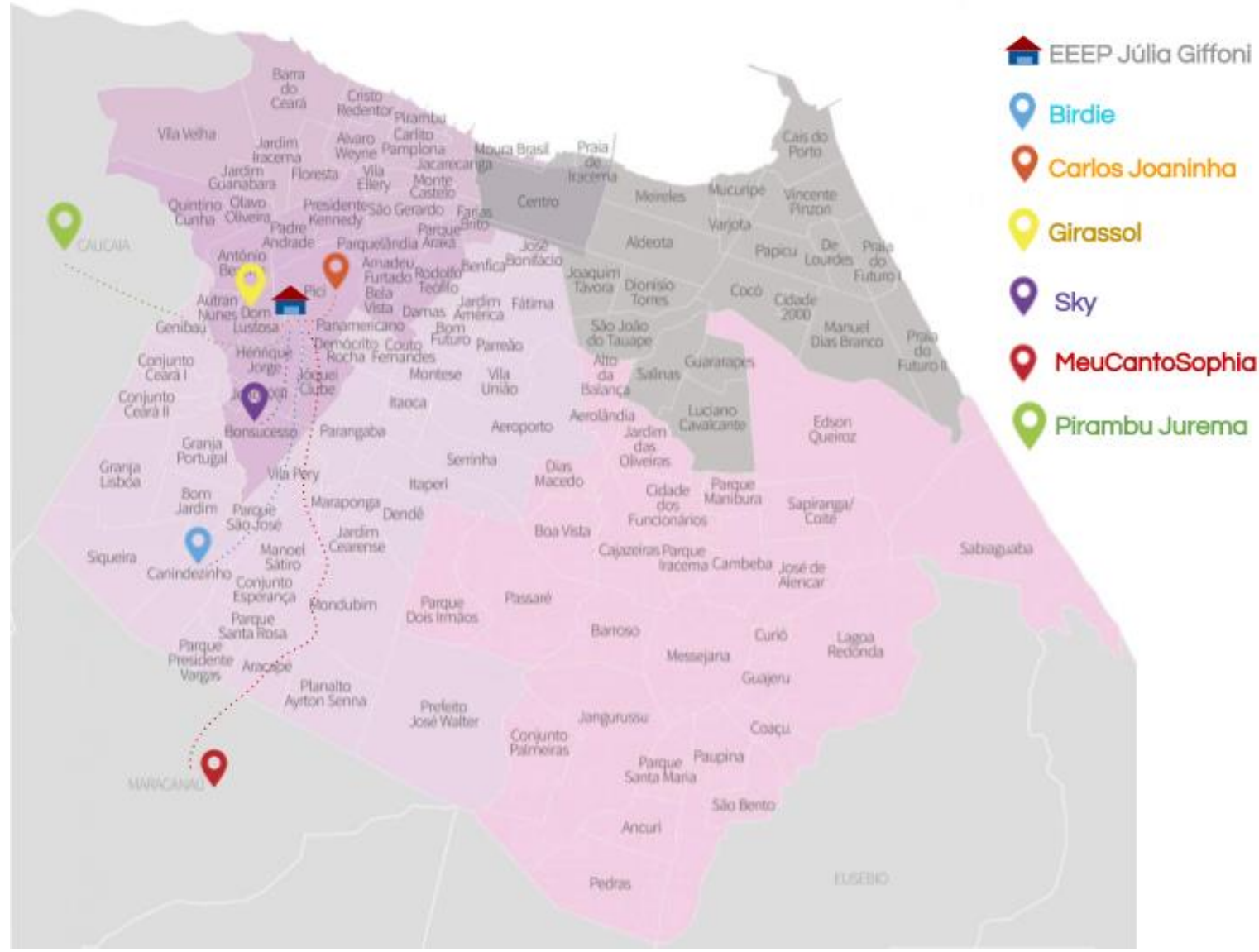

Figura 3: Distância da casa dos participantes até a escola.

Fonte: produção própria sobre mapa produzido pela

Secretaria de Urbanismo e Meio Ambiente do município de Fortaleza (SEUMA).

FALCÃO NETO, Fernando Moreira; ALBUQUERQUE, Luiz Botelho. A construção da disposição narrativa em uma pesquisa (auto)biográfica sobre o despertar musical.Revista da FUNDARTE. Montenegro, p.166-187, ano 20, no 40, janeiro/março de 2020.Disponível em: http://.seer.fundarte.rs.gov.br/index.php/RevistadaFundarte/index> 31 de março de 2020 


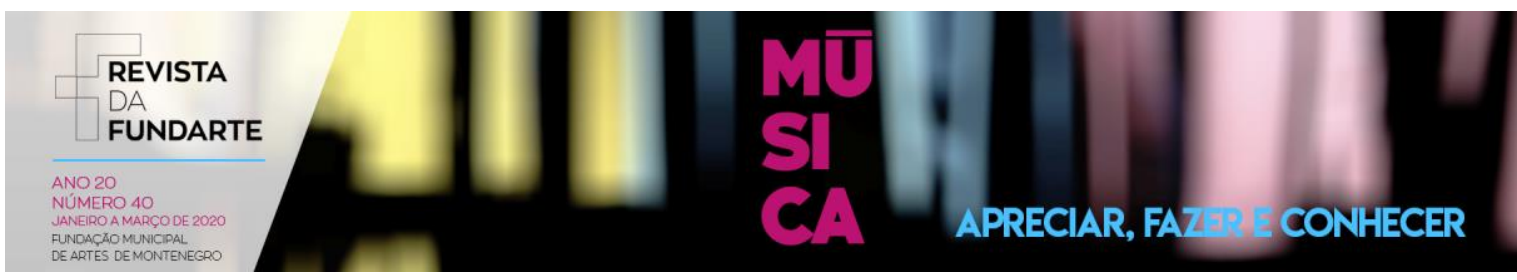

\section{PRIMEIROS RESULTADOS: NARRAR COM TERRA E COR}

O primeiro encontro presencial do CRBM aconteceu em um sábado à tarde. $O$ grupo ensaiava desde às 8 horas. Ao chegar à escola, o pesquisador foi à sala de artes, a música tomava conta do corredor. O professor Fabrício prometeu liberar os quatro coralistas em instantes. Às 14h15, começaram a entrar na sala. Conversamos um pouco sobre como seria o funcionamento, concordamos que os três gravadores ficariam ligados durante todo o tempo e iniciamos: leitura do roteiro, a primeira Caixa de Música e As Cores do Ceará.

O pesquisador assumiu a função de mediador e, ao explicar como funcionaria a atividade As Cores do Ceará, apresentou uma cartolina com amostras de areias coloridas. Para começar, colocou sobre a mesa pequenas faixas de papel com as palavras: alegria, pertencimento, conexão, amizade, gratidão, afeto/amor, compaixão, compreensão, confiança, esperança e fé, segurança, generosidade, acreditância, impaciência, desânimo, raiva, medo, incompreensão, insegurança, tristeza, deslocamento, acolhimento e tranquilidade. O grupo acrescentou: entusiasmo, empatia, união, ansiedade, confuso, cansada e neutro.

Cada um escolheu a sensação mais próxima ao que sentia naquele instante. Um turbilhão veio à tona, a semana e o decorrer daquele dia eclodiram na escolha das palavras. Em seguida, o grupo definiu uma cor para cada sentimento (figura 4). Coragem foi acrescentada ao catálogo, apenas no último encontro, no primeiro sábado de fevereiro de 2020. O barulho da areia ao cair na garrafa, a quantidade depositada e as falas que buscavam justificar a escolha da cor constituem momentos narrativos significativos. Além de colaborar para se criar uma abertura à troca intersubjetiva, esses atos de narrativas visuais fortificaram, de forma gradual, a disposição de narrar e escutar a própria história. Assim foi possível liberar os ouvidos para reconhecer que a vida, até o que há de menos bonito nela, é o principal motor para se buscar a música. Se a palavra não diz, se a fala é econômica, se a boca, ao dizer, não suporta a emoção, cantar é o caminho para comunicar. A garrafinha com areia colorida também nos serviu como comunicação.

FALCÃO NETO, Fernando Moreira; ALBUQUERQUE, Luiz Botelho. A construção da disposição narrativa em uma pesquisa (auto)biográfica sobre o despertar musical.Revista da FUNDARTE. Montenegro, p.166-187, ano 20, no 40, janeiro/março de 2020.Disponível em: http://.seer.fundarte.rs.gov.br/index.php/RevistadaFundarte/index> 31 de março de 2020 

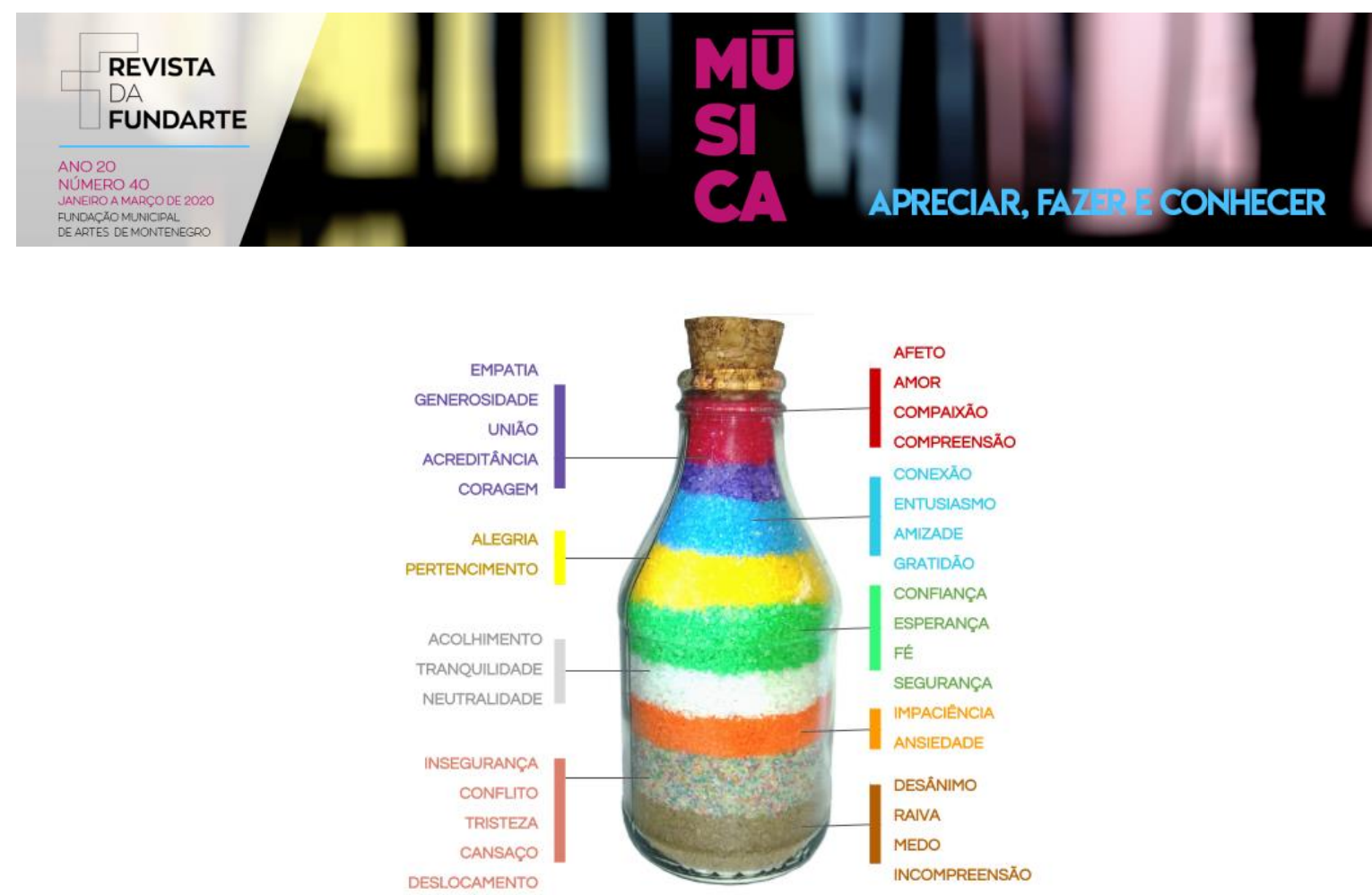

Figura 4: Garrafinha das sensações - As Cores do Ceará.

Fonte: produção própria.

Para o início desta discussão, publicamos os dois primeiros momentos da atividade (tabela 1). O primeiro momento, se refere ao sentimento da chegada, a escolha da palavra antes de atribuirmos significados às cores. O segundo momento, foi a primeira cor escolhida em referência a uma emoção. Cada agente-colaborador pegou uma garrafa de vidro, que estava no centro da mesa, colocou a sua inicial na rolha e a entregou ao colega do lado direito. Depois, escolheu um sentimento que queria trazer ao grupo, depositou a areia com a cor correspondente e devolveu a garrafa ao colega do lado esquerdo, com um abraço. Pirambu Jurema, o pesquisador, entregou amor a MeuCantoSophia, que entregou pertencimento a Birdie. Essa entregou confiança a Sky, que entregou entusiasmo a Girassol. Ela, então, entregou acreditância ao Carlos Joaninha, que entregou tranquilidade ao Pirambu Jurema.

Tabela 1: Atividade As Cores do Ceará.

\begin{tabular}{|l|l|}
\hline & \multicolumn{1}{|c|}{ I MOMENTO } \\
\cline { 2 - 3 } & A minha palavra, muito sincera, é gratidão. Por estar vivendo esse \\
\hline
\end{tabular}

FALCÃO NETO, Fernando Moreira; ALBUQUERQUE, Luiz Botelho. A construção da disposição narrativa em uma pesquisa (auto)biográfica sobre o despertar musical.Revista da FUNDARTE. Montenegro, p.166-187, ano 20, no 40, janeiro/março de 2020.Disponível em: http://.seer.fundarte.rs.gov.br/index.php/RevistadaFundarte/index> 31 de março de 2020 


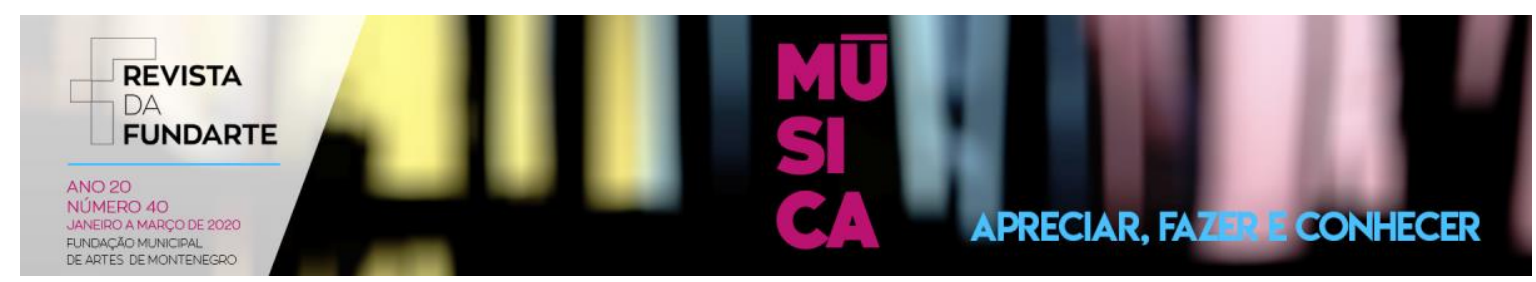

\begin{tabular}{|c|c|}
\hline \multirow{3}{*}{$\begin{array}{l}\text { PIRAMBU } \\
\text { JUREMA }\end{array}$} & $\begin{array}{l}\text { momento, por vocês terem aceitado essa proposta e estarmos } \\
\text { iniciando esse processo. }\end{array}$ \\
\hline & II MOMENTO \\
\hline & $\begin{array}{l}\text { Eu vou começar com amor. Eu acho que tudo que inicia com amor } \\
\text { dá certo. Eu acho que tudo que a gente fizer tem que ser com amor, } \\
\text { qualquer coisa. Então, eu desejo que o nosso grupo tenha muito } \\
\text { amor. }\end{array}$ \\
\hline \multirow{4}{*}{ BIRDIE } & I MOMENTO \\
\hline & $\begin{array}{l}\text { Ansiedade, assim, eu não sei explicar, porém... Eu estou me } \\
\text { sentindo muito ansiosa por alguma coisa... }\end{array}$ \\
\hline & II MOMENTO \\
\hline & $\begin{array}{l}\text { Eu traria confiança, porque eu acho que a gente tem que confiar no } \\
\text { que a gente vai fazer. }\end{array}$ \\
\hline \multirow[b]{2}{*}{$\begin{array}{l}\text { CARLOS } \\
\text { JOANINHA }\end{array}$} & I MOMENTO \\
\hline & $\begin{array}{l}\text { Bem, a palavra que eu escolhi foi tranquilidade. Porque, apesar de } \\
\text { tudo, todas as situações que passaram, até hoje, no caso, essas } \\
\text { duas últimas semanas que eu comecei a trabalhar, então, tem toda } \\
\text { aquela questão da pressão. O trabalho é algo bem complicado, mas } \\
\text { ao mesmo tempo não é. É algo completamente difícil, mas eu tento } \\
\text { sempre manter essa minha forma, essa minha forma calma de ser. } \\
\text { Então, eu estou sempre assim, sempre tranquilo, dificilmente, você } \\
\text { vai me ver com raiva de alguma coisa. Dificilmente, você vai me ver } \\
\text { estressado, principalmente, estressado. Então, é sempre assim. E } \\
\text { fico mais tranquilo, muito mais tranquilo, e também alguns outros } \\
\text { sentimentos, quando eu venho para cá. Porque, quando eu venho } \\
\text { para cá, muda, o ar muda... Eu vejo todo mundo que tá aqui: Ah, vai } \\
\text { todo mundo cantando. Está todo mundo cantando! Às vezes, estão } \\
\text { se divertindo. Às vezes, aqueles momentos sérios, mesmo com } \\
\text { aquela pressão de escola, trabalho...Sei lá, [vai] fazer prova, alguma } \\
\text { coisa do tipo, mas está aquele pessoal ali, está todo mundo ali! E }\end{array}$ \\
\hline
\end{tabular}

FALCÃO NETO, Fernando Moreira; ALBUQUERQUE, Luiz Botelho. A construção da disposição narrativa em uma pesquisa (auto)biográfica sobre o despertar musical.Revista da FUNDARTE. Montenegro, p.166-187, ano 20, no 40, janeiro/março de 2020.Disponível em: http://.seer.fundarte.rs.gov.br/index.php/RevistadaFundarte/index> 31 de março de 2020 


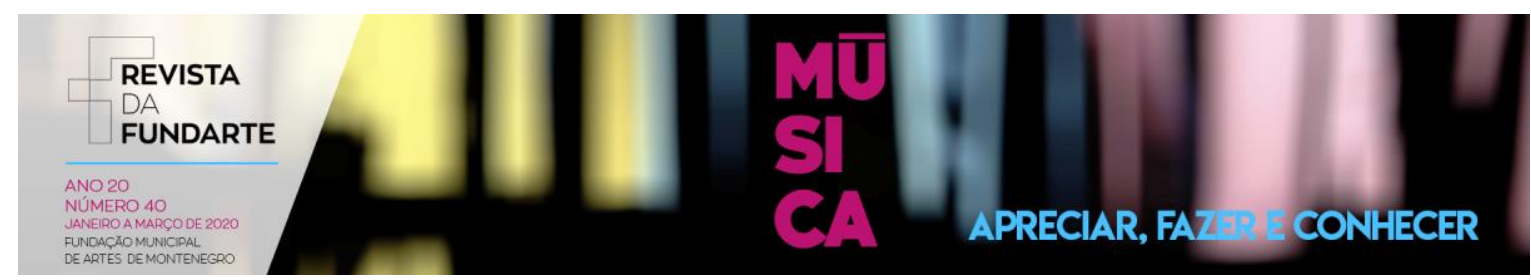

\begin{tabular}{|c|c|}
\hline & $\begin{array}{l}\text { como diz a palavra, quem canta os seus males espantam! Palavra } \\
\text { não, frase, né? Então é isso, é esse o sentimento que eu sempre } \\
\text { estou, eu sempre tento manter isso, a minha tranquilidade. }\end{array}$ \\
\hline & II MOMENTO \\
\hline & $\begin{array}{l}\text { Eu vou colocar tranquilidade. Que seja bem tranquilo mesmo, que a } \\
\text { gente consiga fazer as coisas mais tranquilo mesmo... }\end{array}$ \\
\hline & I MOMENTO \\
\hline GIRASSOL & $\begin{array}{l}\text { Nesse exato momento, agora. Tipo, eu passei, estava passando uma } \\
\text { semana muito ruim... Mas agora, eu estou me sentindo acolhida, não } \\
\text { estou sentindo nem pressão, nem raiva. Estou me sentindo em paz, } \\
\text { pelo menos agora. }\end{array}$ \\
\hline & II MOMENTO \\
\hline & $\begin{array}{l}\text { Eu vou colocar acreditância. Por conta de confiarmos mais em nós } \\
\text { mesmos, para seguirmos, sem termos muitas recaídas. Confiarmos } \\
\text { mais no nosso potencial. }\end{array}$ \\
\hline & I MOMENTO \\
\hline $\begin{array}{l}\text { MEU } \\
\text { CANTO } \\
\text { SOPHIA }\end{array}$ & $\begin{array}{l}\text { A palavra que eu escolhi foi deslocamento, porque eu me encontro } \\
\text { em um momento de transição. Não é bem um sentimento, mas é } \\
\text { uma palavra que, das que estavam aí, mais se enquadra no } \\
\text { momento que estou hoje e, quando você está em um deslocamento, } \\
\text { nem você quer dizer que você tá triste nem feliz, tá agindo. [Pirambu: } \\
\text { Mas você se sente deslocada?] Não, eu estou em processo de } \\
\text { deslocamento. No sentido de estar... [Pirambu: em transição] É, } \\
\text { saindo de um canto e indo para outro. [Pirambu: não pertence a } \\
\text { nenhum, ainda está em processo de trânsito]. Isso. Eu sinto como } \\
\text { se, tanto agora, quanto esta... Não sei se porque eu acabei de sair } \\
\text { da faculdade. Essa experiência que eu vou ter aqui, vai me fazer } \\
\text { olhar para outras coisas. Mas eu estou bem, nessa caminhada, mas } \\
\text { é... A palavra deslocamento me lembra o caminho, então eu estou } \\
\text { andando, eu estou no caminho. Então, eu me sinto nessa questão, }\end{array}$ \\
\hline
\end{tabular}

FALCÃO NETO, Fernando Moreira; ALBUQUERQUE, Luiz Botelho. A construção da disposição narrativa em uma pesquisa (auto)biográfica sobre o despertar musical.Revista da FUNDARTE. Montenegro, p.166-187, ano 20, no 40, janeiro/março de 2020.Disponível em: http://.seer.fundarte.rs.gov.br/index.php/RevistadaFundarte/index> 31 de março de 2020 


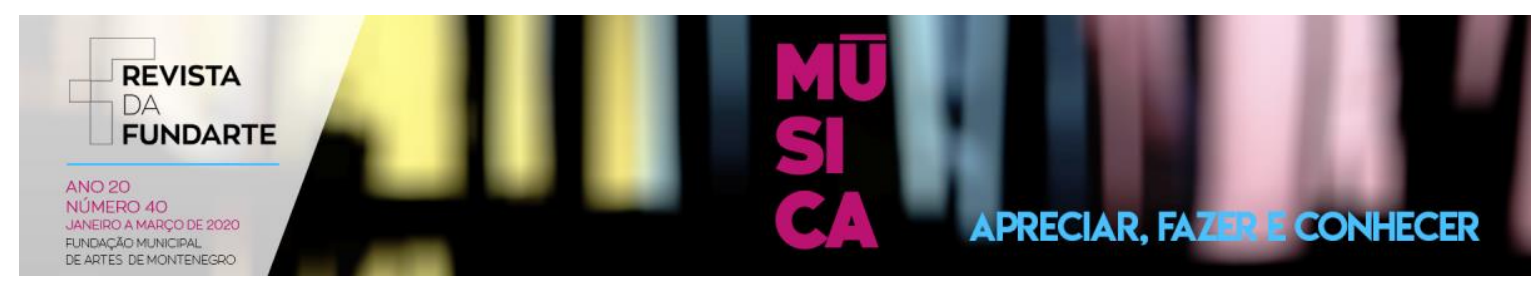

\begin{tabular}{|c|c|}
\hline & $\begin{array}{l}\text { nesse momento. [Pirambu: Entendi. Tateando o seu pertencimento, } \\
\text { não é?] É...Também, mas no sentimento de que eu estou em busca } \\
\text { de algo que eu ainda não encontrei. }\end{array}$ \\
\hline & II MOMENTO \\
\hline & $\begin{array}{l}\text { Pertencimento. Que durante esse processo a gente se sinta um } \\
\text { conectado com o outro e sinta que a gente pertence a esse grupo. } \\
\text { Eu gosto muito dessa palavra. }\end{array}$ \\
\hline \multirow{4}{*}{ SKY } & I MOMENTO \\
\hline & $\begin{array}{l}\text { Eu escolhi a palavra cansada e ela vai muito além do cansaço físico, } \\
\text { porque eu acho assim, que isso está me representando por esses } \\
\text { tempos, mas é mais o cansaço mental. [Pirambu: Você está aqui } \\
\text { desde às } 8 \text { horas, não comeu direito...] É... Mas não } \\
\text { necessariamente é o cansaço físico, eu falo assim de uma semana } \\
\text { atribulada que eu tive. Ontem, eu presenciei uma coisa dentro da } \\
\text { universidade que me tocou muito... Eu faço curso de línguas na } \\
\text { UECE }{ }^{4} \text { e, ontem, eu presenciei uma cena de opressão lá dentro, isso } \\
\text { mexeu muito comigo. E aí, isso me fez refletir muito sobre algumas } \\
\text { coisas... Sobre o meu posicionamento, sobre as coisas que eu } \\
\text { acredito. E também a questão do meu trabalho, que é um trabalho } \\
\text { que me oferece um pouco de risco, que me deixa bastante cansada, } \\
\text { que, às vezes, me deixa desmotivada. Mas, eu acho que essa } \\
\text { palavra é o que está me resumindo agora, cansada. }\end{array}$ \\
\hline & II MOMENTO \\
\hline & $\begin{array}{l}\text { A palavra que eu escolhi foi entusiasmo. Eu já cheguei a comentar que } \\
\text { aconteceram algumas coisas, mas não quero que isso atrapalhe esse } \\
\text { processo. Eu quero me orgulhar de ter feito isso aqui, daqui algum tempo. } \\
\text { Quero levar essa experiência aqui por toda a minha vida. [...] }\end{array}$ \\
\hline
\end{tabular}

Ao escolher uma cor e falar o que sentia, cada um trouxe as suas buscas, alguns as referenciaram pelos acontecimentos da semana, como Sky, Carlos e

\footnotetext{
4 Universidade Estadual do Ceará.

FALCÃO NETO, Fernando Moreira; ALBUQUERQUE, Luiz Botelho. A construção da disposição narrativa em uma pesquisa (auto)biográfica sobre o despertar musical.Revista da FUNDARTE. Montenegro, p.166-187, ano 20, no 40, janeiro/março de 2020.Disponível em: http://.seer.fundarte.rs.gov.br/index.php/RevistadaFundarte/index> 31 de março de 2020
} 


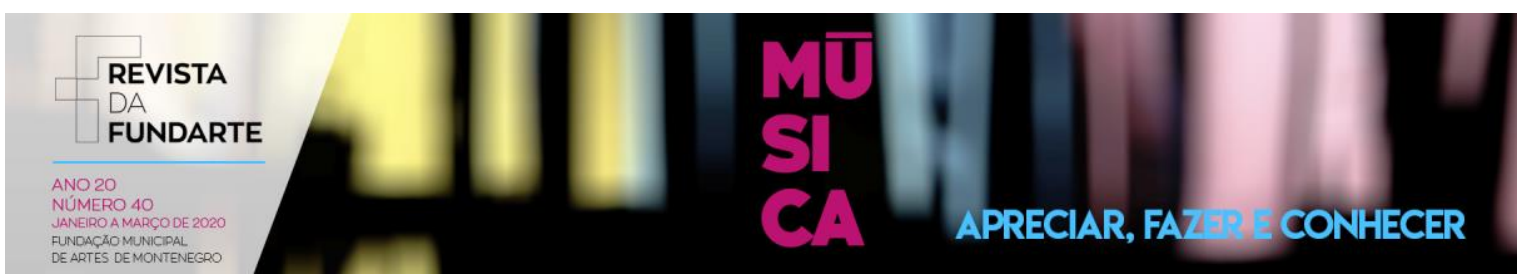

Girassol. MeuCantoSophia falou de um momento de vida e Birdie falou pouco, mas revelou que a sua fala buscava reconhecer se ali seria um espaço onde encontraria escuta. Sky falou de cansaço mental, necessidade de se reconhecer nos valores que defendia e na forma que agia; como entrega, nos presenteou com o entusiasmo. Carlos revelou a apreensão de quem, há quinze dias, iniciara uma nova fase de vida, a de trabalhador; nos entregou o que cultivava, a tranquilidade. Girassol narrou sobre uma semana agitada, mas, ali, ela poderia falar dela mesma e não se importar com a fala dos outros, encontrou no grupo o acolhimento que buscava e entregou a acreditância. MeuCantoSophia chegou deslocada e entregou o que procurava, 0 pertencimento. Birdie chegou ansiosa com a novidade e entregou a confiança. $O$ movimento de apropriar, interiorizar e traduzir, revela-se na narrativa como prefigurar, configurar e reconfigurar. Experenciar, sentir, reordenar e criar um novo sentido para o seu próprio modo de agir.

\section{CONSIDERAÇÕES FINAIS}

O Círculo Reflexivo Biográfico possibilita, ao pesquisador, relacionar-se de forma periódica com os colaboradores da pesquisa a poder, assim, acompanhar o processo de construção (auto)biográfica. A relação intersubjetiva entre todos os participantes aprofunda a performance narrativa, permitindo que a fala torne-se menos desconfiada e vigiada.

Observamos, entre os colaboradores, uma necessidade narrativa latente. Há uma procura por estar em espaços que proporcionem a escuta atenta e amorosa, com qualquer linguagem que seja. Como dispositivo de pesquisa (auto)biográfica, a potência do CRB é a construção de uma ambiência que proporcione a pesquisaformação-intervenção. A permitir, em um espaço de escuta democrático, seguro e plural, que os participantes direcionem os seus processos narrativos e (auto)formativos.

Percebemos que o grupo Phylos funciona como lugar para a elaboração de uma fala que não encontra facilmente outros espaços onde possa ser produzida e compartilhada. O CRBM surgiu como um segundo ambiente para a criação desta expressão. Com isso, reconhecemos a significância de uma escola pública oferecer FALCÃO NETO, Fernando Moreira; ALBUQUERQUE, Luiz Botelho. A construção da disposição narrativa em uma pesquisa (auto)biográfica sobre o despertar musical.Revista da FUNDARTE. Montenegro, p.166-187, ano 20, no 40, janeiro/março de 2020.Disponível em: http://.seer.fundarte.rs.gov.br/index.php/RevistadaFundarte/index> 31 de março de 2020 


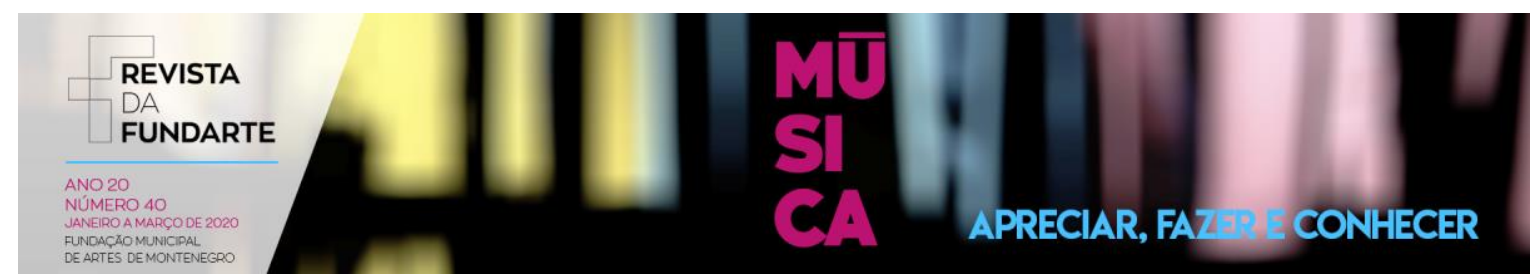

formação artística a quem desejar tê-la, independente de vínculo institucional. Desejamos que a experiência se amplie e o poder público reconheça, institucionalmente, a importância do saber musical e artístico para a formação intelectual e direcionamento à ação social.

\section{REFERÊNCIAS}

ASIHVIF, ASSOCIAÇÃO INTERNACIONAL DAS HISTÓRIAS DE VIDA EM FORMAÇÃO. Carta da ASIHVIF: nossa carta. In: Revista Brasileira de Pesquisa (Auto) Biográfica. Salvador, v. 01, n. 01, p. 177-179, jan./abr. 2016.

BARROSO, Gustavo. Terra de Sol. Rio de Janeiro: Benjamin de Aguila Editor, 1912.

BONDÍA, Jorge Larrosa. Tremores: escritos sobre experiência. Belo Horizonte: Autêntica, 2015.

BOURDIEU, Pierre. O poder simbólico. Rio de Janeiro: Bertrand Brasil, 2012.

FERRAROTTI, Franco. Sobre a autonomia do método autobiográfico. In: NÓVOA, A.; FINGER, M. (Orgs.) O método (auto)biográfico e a formação. São Paulo: Paulus, 2010, p. 31-58.

GALENO, Juvenal. Lendas e canções populares. Fortaleza: Editora Henriqueta Galena, 1969.

MOTA, Leonardo. Cantadores. Rio - São Paulo - Fortaleza: ABC editora, 2002.

OLINDA, Ercília de. Grupo Fantasia: esperança, responsabilidade e alegria. Fortaleza: Expressão Gráfica Editora, 2009.

OSTROWER, Fayga. Criatividade e processos de criação. Petrópolis: Editora Vozes, 1987.

PINEAU, Gaston. As histórias de vida em formação: gênese de uma corrente de pesquisa-ação-formação existencial. In.: Educação e Pesquisa, São Paulo, v.32, n.2, p. 329-343, maio/ago. 2006.

RICOEUR, Paul. Tempo e narrativa - Tomo 1. Campinas: Papirus editora, 1994.

ROGÉRIO, Pedro. Pessoal do Ceará: formação de um campo e um habitus musical na década de 1970. Dissertação (Mestrado em Educação) - Universidade Federal do Ceará, Faculdade de Educação, Programa de Pós-Graduação em Educação Brasileira, Fortaleza, 2006.

SANTAELLA, Lucia. Matrizes da linguagem e pensamento: sonora, visual, verbal - aplicações na hipermídia. São Paulo: lluminuras e FAPESP, 2005.

FALCÃO NETO, Fernando Moreira; ALBUQUERQUE, Luiz Botelho. A construção da disposição narrativa em uma pesquisa (auto)biográfica sobre o despertar musical.Revista da FUNDARTE. Montenegro, p.166-187, ano 20, no 40, janeiro/março de 2020.Disponível em: http://.seer.fundarte.rs.gov.br/index.php/RevistadaFundarte/index> 31 de março de 2020 


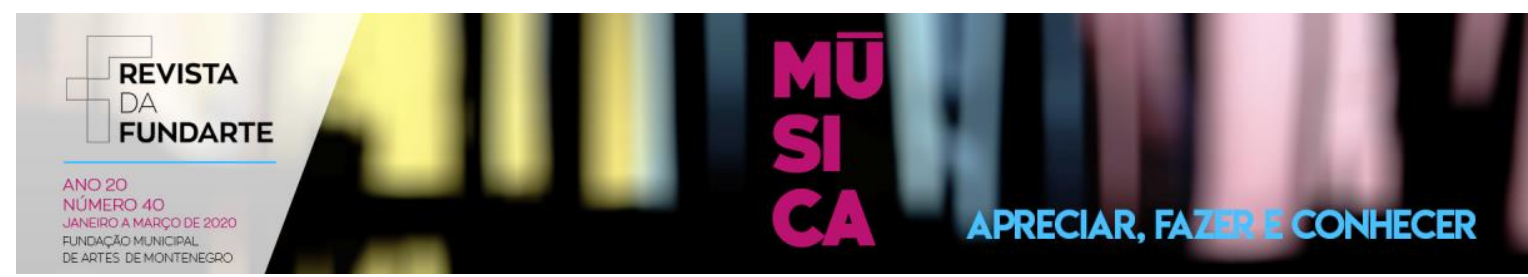

SILVA, Marcos Antônio Nunes da. Música cearense através do canto coral: estudo de caso com o grupo Phylos. Dissertação (Mestrado Profissional em Artes) Universidade Federal do Ceará, Programa de Pós-graduação Profissional em Artes, Fortaleza, 2016.

SILVINO, Izaíra. ....ah, se eu tivesse asas... Fortaleza, Expressão Gráfica e Editora Ltda, 2007.

FALCÃO NETO, Fernando Moreira; ALBUQUERQUE, Luiz Botelho. A construção da disposição narrativa em uma pesquisa (auto)biográfica sobre o despertar musical.Revista da FUNDARTE. Montenegro, p.166-187, ano 20, no 40, janeiro/março de 2020.Disponível em: http://.seer.fundarte.rs.gov.br/index.php/RevistadaFundarte/index> 31 de março de 2020 